\title{
Horacio Coppola: Towards an Aesthetic Genealogy
}

Eleni Kefala

University of St Andrews

This is an Accepted Manuscript of an article published by Taylor \& Francis in the journal History of Photography 40:4 (November 2016), available online: http://dx.doi.org/10.1080/03087298.2016.1236887

Although a milestone in the history of Latin American photography, the work of Horacio Coppola is little known outside Argentina. His unorthodox angles and tilting frames, his attention to industrial and urban themes, and his experimentation with different lenses in the period between 1927 and 1931 were in absolute synchrony with the precepts of European New Vision and New Objectivity photography, and with American straight photography. That Coppola's visual idiom was in tune with the latest photographic developments in interwar Europe is obvious. What remains unclear is how exactly he achieved that synchrony. Several scholars have wrestled with this question, which nevertheless remains elusive due to lack of evidence of direct contact with European photography prior to his studies at the Berlin Bauhaus in 1932 and his repeated attempts to downplay the influence contemporary photographers had on his work. The article provides a systematic study of Coppola's aesthetic genealogy and his photographic borrowings through a critical examination of his early pictures and theoretical writings. It teases out possible direct and indirect channels of dialogue with the New Vision, New 
Objectivity, and straight photography in the second half of the 1920s, and probes the reasons behind Coppola's reluctance to admit a connection with contemporary European photography in particular.

Keywords: Alfredo Guttero (1882-1932), José Ortega y Gasset (1883-1955), Le Corbusier (1887-1965), Horacio Coppola (1906-2012), Argentina, New Vision, New Objectivity, straight photography, avant-garde, Buenos Aires, Latin America, $1920 s, 1930 s$.

Horacio Coppola is Argentina's first truly modern photographer. If, according to Henry Miller, Brassai is the 'eye of Paris', Coppola is that of Buenos Aires. ${ }^{1} \mathrm{He}$ is best known for his album Buenos Aires 1936: visión fotográfica, a volume commissioned by the mayor of Buenos Aires, Mariano de Vedia y Mitre, to commemorate the fourth centennial of the first foundation of the city by Pedro de Mendoza in 1536. Notwithstanding a milestone in the photographic modernism of Latin America and a fine example of Neue Sachlichkeit, or 'New Objectivity' photography, the album was far less experimental in nature than Coppola's earlier work, which was in absolute synchrony with European 'New Vision' and North American 'straight photography'. That the Argentine was in step with his contemporaries within and outside the Bauhaus before his sojourn there in 1932 is a truism. What remains uncertain is how precisely he attained that synchrony.

Scholarship has been ambiguous on the matter due to lack of evidence of an explicit liaison with European avant-garde photography before 1932. Coppola's own 
silence regarding his readings on photography prior to his studies at the Berlin Bauhaus between October 1932 and April 1933, his rebuff of the impact the school exerted on his work, and the absence of relevant books from that period in his personal library have baffled researchers, who continue to grapple with the conundrum. While almost all scholars agree on Coppola's possible contact with European visual aesthetics via a set of mediated sources, and especially cinema, prior to 1931, some speak of an intuitive photographer who was born 'modern' and whose knowledge of photographic developments outside pictorialist Argentina was awfully thin. ${ }^{2}$ Others put forward an American link, while a third group seems to accept a pre-Bauhaus influence of avantgarde photography. ${ }^{3}$ Natalia Brizuela, for instance, entertains the possibility that the correspondence between Coppola's Siete temas: Buenos Aires (Seven Subjects: Buenos Aires), a series of photographs published in the influential magazine Sur in 1931, and European New Vision photography might have sprung from his acquaintance with the work of Alfred Stieglitz. ${ }^{4}$ Brizuela speculates that in 1930 Coppola may have gained access to Stieglitz's geometricised skies from his sequence Equivalents, or perhaps to the final issue of Camera Work (1917), a showcase of Paul Strand's aesthetic outlook (namely his abstract prints and manifesto of straight photography), via the editor of Sur, Victoria Ocampo, who had visited the Maecenas of American photography at his New York gallery in that same year. ${ }^{5}$ By 1917, Strand had prefigured several formal themes of German New Objectivity photography with its emphasis on the object photographed and a straight, matter-of-fact approach, as well as a number of elements of the more experimental strand of New Vision photography, among them the jazzy high and lowangle shots and the tilted camera that Coppola openly espoused in 1931 (figure 1). ${ }^{6}$ 
Strand's clarion call to 'a real respect for the thing' in 1917 heralded, at least nominally, the demise of Pictorialism that had thrived around the globe since the 1880s, while the 'absolute unqualified objectivity' that he saw in some of Stieglitz's photographs would materialise as the gonfalon of New Objectivity painting and photography in Europe, particularly in the Weimar Republic throughout the 1920s. ${ }^{7}$ His abstract pictures, a series of tilted photographs of chairs, shadows, porch railings, ridge poles, and deconstructed skies taken at his cottage in Twin Lakes in 1916, arguably headed the international photographic vanguard. ${ }^{8}$ Strand's abstract visuality had been empowered by his study of Cézanne, Picasso, and Braque, undertaken at Stieglitz's prompting. By turning his dwelling into an unheimlich place through his 'freewheeling vision', Strand latched onto what would soon constitute the rallying cry of the New Vision; ${ }^{9}$ the urge to revolutionise visual aesthetics, to see with a neue Auge (new eye), was a precept shared by any bona fide avant-gardist across the artistic spectrum.

The Bauhaus photographer and painter László Moholy-Nagy's opus magnum Malerei Fotografie Film (Painting Photography Film) would formally set the tone for this neue Optik (literally, new lens; new vision) in $1925 .{ }^{10}$ The familiar-turned-unfamiliar, which Dziga Vertov trumpeted in his 1924 documentary Kino-Glaz (Kino-Eye), comprised the gist of Moholy-Nagy's appeal - manifest in his iconic vertical shot of the Bauhaus balconies (1926) ${ }^{11}$ - as well as of that of Aleksandr Rodchenko, the Russian constructivist and major representative of New Vision photography who championed Vertov's view: 'I am kino-eye. I am mechanical eye. I, a machine, show you the world as only I can see it. [...] My path leads to the creation of a fresh perception of the world. I decipher in a new way a world unknown to you'. ${ }^{12}$ Rodchenko had admittedly reached 
Strand via Vertov. With his di sotto in sù and high-angle photographs of his apartment on Myasnicka street in 1925, notes Victor Margolin, he 'reinvented the building, making of it a series of novel views', and so did Coppola six years later with his worm's and bird'seye shots of his building on 3060 Corrientes Street in Buenos Aires. ${ }^{13}$

Coppola's tilting frame may well have ensued from an American affair, as Brizuela implies, had Ocampo's suitcase carried the final issue of Camera Work in 1930, but the scholar concedes that the photographer most likely had not 'seen or read' any work by Strand before $1931 .{ }^{14}$ I am therefore less inclined to settle on this story than on the one that sees Coppola becoming aware of New Vision photography during his Bildungsreise to Italy, Germany, France, and Spain between December 1930 and May 1931 - in other words, prior to his 1931 photographs, incidentally taken with the brand new Leica $35 \mathrm{~mm}$ that he had purchased in Europe ${ }^{15}$ For all that Brizuela acknowledges that photographs like those of Siete temas are 'in tune, no doubt, with the photographs of the New Vision' as they 'contain all the formal elements of the European New Vision', she posits that in 1931 Coppola 'does not know [them] yet'. ${ }^{16}$ Based on the absence of relevant books in his library and of any mention on his part of an acquaintance with avant-garde photography (either by visiting exhibitions or simply by sifting through publications in bookshops, museums, art galleries, and at gatherings with fellow cognoscenti), Brizuela seems to infer that Coppola learnt virtually nothing about New Vision photography during those months in Europe. Instead, she attributes his affinity with the New Vision to a number of mediated sources - I will pick up on the idea of mediation later - and, perhaps, through Stieglitz. ${ }^{17}$

It is true that Coppola would return to Europe within a few months with a view to 
becoming not a photographer but an art critic. However, is it not strange that someone whose plan was to join the Department of Photography at the University of Marburg, part of the Art History Department under Richard Hamann, should be indifferent to all things photographic, including to the New Objectivity (the dominant trend in the German artistic landscape), during that first trip? ${ }^{18}$ I find this scenario highly unlikely, if selfdefeating. How else could we explain the neue Optik of Coppola's bird's eye view of the two ships and the three small boats in Puerto, Vuelta de Rocha (Port, Vuelta de Rocha) (1931) - published as part of his photo-essay Siete temas - whose similarity to MoholyNagy's high-angle photograph of a little boat and a sailing vessel in Boat is arresting, or the extreme vertical shot in Calle Corrientes 3060 (3060 Corrientes Street) (1931) (figure 2) and its extraordinary kinship with Rodchenko's Arbat, Street Traffic (1932), André Kertész's Crossroads, Blois (1930), and Moholy-Nagy's Gangplank from Above (1930)? Coppola's and Moholy-Nagy's photographs in particular are panegyrics on geometry whose striking similarity, both in conception and execution, is evident in their focus on the round, flat-shaped hats, the rectangular block pavement, and the feast of parallel and intersecting lines that define the composition. ${ }^{19}$ How should we interpret the obvious dialogue between his low-angle photographs of trees in Pulmón de manzana (Block Lung) (1931) and Rodchenko's Pine Tree, Pushkino (1927), or between his industrial themes in a number of pictures captioned 'Buenos Aires, 1931' and in Portón y Grúa (Crane) (1931) (figure 3), and Albert Renger-Patzsch's industrial photographs or Germaine Krull's Métal (1928) (figure 4), which, like Crane, aestheticises the fortuitous geometry of tower cranes? $?^{20}$ What are we supposed to make of the factory funnels of Puerto (Port) (1931) (figure 5) when faced with those of Renger-Patzsch - in 
photographs like Zeche 'Viktoria Mathias' in Essen (Viktoria Mathias Mine in Essen (Viktoria Mathias Mine in Essen) (1929), ${ }^{21}$ the vertical projection of the three smokestacks in the background whose top end is deliberately left out of the frame, is figuratively rendered infinite, suggesting an apotheosis of industrial modernity - and those of Charles Sheeler, notably his photographs of the Ford Motor Company's new River-Rouge plant in 1927, or his fixation with shadows, a leitmotif of the New Vision? ${ }^{22}$

Almost all of Coppola's 1931 high-angle pictures taken from his house on 3060 Corrientes Street are formal studies of shadow and so is Mateo y su victoria (Mateo and his Victoria) (1931) (figure 6). A 'defence of a shadow', in Jorge Schwartz's terms, this high-angle photograph of a man, his cart, and their projected shadows on the street is rotated to grant autonomy to the shadow. Coppola 'seems to breathe life into these shadows, endowing them with the illusion of independence', says Schwartz, pointing out that 'the Bauhaus made great use of shadow photography'. He offers as an example Otto Umbehr (known as Umbo), 'a leading photographer of the German School' who 'even managed to take a photo of his shadow projected onto his own body'. ${ }^{23}$ It is true that Mateo and his Victoria bears strong resemblance to Umbo's The Eerie Street (1928). ${ }^{24}$ Shot vertically from a high-angle, the latter captures the unheimlich shadows of two pedestrians and a man on his cycle cart. The otherworldly shadows grow into autonomous entities, dwarfing the human figures from which they emanate. ${ }^{25}$

Scholars agree that the 'radical' turn in Coppola's aesthetics, what Luis Priamo dubs 'this gigantic jump', occurred in 1931, immediately after his first trip to Europe. ${ }^{26}$ The Argentine readily confirmed various visits to contemporary art exhibitions, his familiarisation with the Italian Novecento ('in Rome, an exhibition of work by Umberto 
Boccioni introduced me to Il Novecento'), and his purchase of Élie Faure's Histoire de l'art (1919-1921), which formed 'the basis of [his] studies'. ${ }^{27}$ David Oubiña informs us that during those trips to Europe, Coppola acquired 'numerous books and journals' on film that would later constitute the 'nucleus' of his personal library, and that 'significantly, his collection does not abound in books of photography of that time'. ${ }^{28} \mathrm{~A}$ known cinephile by then, Coppola's interest in publications on cinema was hardly surprising, but his silence about photography was, and so were his later efforts to downplay his sojourn at the Berlin Bauhaus and any possible impact the director of the photography workshop, Walter Peterhans, may have had on his work. 'A mathematician and an exquisite photographer', noted Coppola with respect to Peterhans whom he met through his future wife, Grete Stern, 'didn't actually teach photography; he just ran the workshop. [...] Everything that they have written about me studying photography at the Bauhaus, is complete nonsense. I did eighteen photos at the Bauhaus workshop. In any case, working there was a very simple business, there was no discussion of the photographs'. ${ }^{29}$ Priamo, among others, indicates that Coppola 'always dismissed Peterhans's influence on his photography', citing as examples his post-Bauhaus use of the medium format and tripod, both amply employed by Peterhans, as opposed to shooting with a $35 \mathrm{~mm}$ lens, which he did prior to his time at the Bauhaus. ${ }^{30}$ Likewise, Coppola maintained a fairly hostile attitude towards Moholy-Nagy (who had already left the Bauhaus by the time the Argentine arrived), probably because of his anti-figurative work. ${ }^{31}$

In many ways, Coppola methodically cultivated the image of a photographer born 'modern'. In his 'Autobiographical Text', published in 1994, he eagerly admitted the 
influence of film directors, painters, authors, poets, art critics, musicians, musicologists, philosophers, psychologists, architects, literary groups and journals, but made no mention of photography, save the cursory statement, 'Photography from Nadar to Edward Weston, from D. O. Hill to Alfred Stieglitz and my contemporaries', which appeared to obscure more than it clarified. ${ }^{32}$ The reference to a couple of pioneer nineteenth-century photographers, both dead by the time he took his first picture, and to American straight photography did not throw light on his photographic borrowings, nor did the passing note on European avant-garde photographers, lumped under the elusive category 'my contemporaries'. I will return to this point later; for the moment, it should be added that the only photographer Coppola recognised as his mentor was his elder brother Armando (1886-1957). Priamo sees the two brothers happily coinciding in their treatment of still lifes. Armando's amateur photography, he says, was 'far removed from the artistic clichés of the time', but unfortunately it is hard to know whether he was, in fact, in touch with post-pictorialist developments in the United States and in Europe in the 1910s and 1920 s. $^{33}$

Schwartz draws a list of publications on photography that were circulating in Europe and could have caught the eye of the photographer in the early months of 1931. Apart from Moholy-Nagy's book-cum-manifesto, there were Franz Roh's trilingual FotoAuge (Photo-Eye) (1929), published as an informal companion to the biggest photographic event of the decade, the Film und Foto exhibition held in Stuttgart from May to July 1929, Karl Blossfeldt's Urformen der Kunst (Art Forms in Nature) (1928), as well as Germaine Krull's Métal (1926) and $100 x$ Paris (1929). ${ }^{34}$ Added to these were Erich Mendelsohn's widely distributed Amerika. Bilderbuch eines Architekten (America: 
An Architect's Picture Book) (1926), Renger-Patzsch's Die Welt ist schön (The World is Beautiful) (1928), Werner Graeff's Es kommt der neue Fotograf! (Here Comes the New Photographer) (1929), and Roh's L. Moholy Nagy: 60 Fotos (1930). ${ }^{35}$ Schwartz argues that the texts and photographs published in Moholy-Nagy's, Roh's, Krull's, and Blossfeldt's books 'had a decisive influence on Coppola's development as a photographer during this experimental period', noting that this 'influence is apparent in Ángulo de escalera [Corner of Staircase], the same photo enlarged in positive and negative, produced in 1929' (figure 7). ${ }^{36}$ Despite the strong currency of negatives in experimental photography, observes Schwartz, for Coppola negative prints were extremely rare - a fact which I believe suggests not a synchrony with but an awareness of the visual language of the European avant-garde. ${ }^{37}$ Although he does not elaborate further on this point, his use of the term 'influence' is crucial because it implies direct contact with European photography already by 1929 - in other words, it indicates that Coppola must have seen some of the experimental pictures of the New Vision. In this light, the assertions made so far by Brizuela and myself do not take full stock of Coppola's radical vision, which may have culminated in 1931, but had, in fact, cropped up in 1927, in the tilted objectivity of his first known photograph Mundo propio (One's Own World) (figure 8), and materialised two years later in the experimental duo Corner of Staircase (positive and negative).

The high-angle photograph in Corner of Staircase (figure 7) and the tilted frame in Materiales de construcción (Construction Materials) (1929) (figure 9) were in perfect tune not only with the New Vision, but also with Coppola's own 1931 photographs. His 'modern' vision was also evident in his pictures of medianeras (sidewalls), a favourite 
theme of the New Objectivity exemplified, for instance, in Franz Lenk's painting Berlin Tenements (1929) and Renger-Patzsch's photograph Cityscape of Meideirich (1930), and in his numerous photographs of the streets and whitewashed houses around the Maldonado stream, all taken in $1929 .{ }^{38}$ The Sachlichkeit, or materialism, of these pictures, the tilted camera and the experimentation with negatives, all vouch for Coppola's pre-1931 neue Auge - an idea endorsed by Priamo who traces a firm continuity between Corner of Staircase (figure 7), Construction Materials (figure 9), and San Gimignano (1931) in terms of subject and formal approach. ${ }^{39}$ The same continuity can be seen in the Sachlichkeit of Construction Materials, the Barricas, Ramos Mejia (Barrels, Ramos Mejía) (1929), and Buenos Aires (1931) (figure 10). ${ }^{40}$ Juan Manuel Bonet reaches a similar conclusion when he corroborates that Coppola's pictures demonstrate that already by the end of the 1920s the photographer 'had assimilated from a distance and in a fragmentary fashion' the visual idiom of Neue Sachlichkeit and the New Vision. ${ }^{41}$

Whence this conceptual and formal affinity, if not from direct contact with the visual lexicon of avant-garde photography? Coppola's aesthetic outfit could not have been fashioned out of thin air. It is my contention that the Argentine must have been aware firsthand of contemporary European and North American photography prior to 1931. Pictorialist Argentina may have been cut off from the latest happenings in the field, as Priamo affirms, but this does not mean that the sizeable crowd of Argentine artists and intellectuals with long sojourns in Europe had not carried in their luggage some of the books and magazines on photography circulating there, which the young Coppola, who 
was moving within a context that was au fait with the European art scene, could have consulted. $^{42}$

Those who are still inclined to veto a direct connection with avant-garde photography (something I would be reluctant to do) are left with a number of mediated influences that have been instrumental in furnishing Coppola's pre-1931 approach to photography. There seems to be a consensus among scholars that the strongest among those influences was European avant-garde film. Oubiña confirms that by 1930 Coppola was abreast of all things cinematic originating in Europe. ${ }^{43}$ Having co-founded Argentina's Film Club in 1929 and acted as its secretary, he was in step with the most recent novelties in Russian, German, and French filmography. ${ }^{44}$ The fifteen screenings organised between 21 August and 27 November 1929 at the Amigos del Arte, a cultural institution whose agenda was the wide dissemination of avant-garde aesthetics, included the Russian fathers of montage Sergei Eisenstein's The Battleship Potemkin (1925) and October (1925), Vsevolod Pudovkin's The End of St. Petersburg (1927), and Vertov's The Sixth Part of the World (1926). ${ }^{45}$ The Club also presented Walter Ruttmann's Berlin: Symphony of a Metropolis (1927) and Man Ray's The Sea Star (1928). The screenings were accompanied by introductory lectures on German cinema and Ruttmann's film (by Guillermo de Torre), French cinema (by Romero Brest), Soviet cinema (by José Luis Romero), and the technical evolution of cinema (by León Klimovsky). Luis Buñuel's Un Chien andalou (1929) was screened only two months after its premiere in Paris and before its first screening in Madrid. ${ }^{46}$

In his 1930 note "'El Cineclub" de Buenos Aires', published in La Gaceta Literaria, de Torre singled out the group's interest in Soviet cinema. 'The most 
significant novelty of the Cineclub of Buenos Aires in relation to all the other similar clubs in Europe', he wrote, 'is the abundance of Soviet Russian "films", of those that European censorship proscribes but here are shown publicly and without much astonishment' ${ }^{47}$ Coppola's familiarity with Russian cinematography is key both to fixing a direct link between his photographic and cinematic output, particularly his experimental documentary short Así nació el obelisco (This is how the Obelisk was Born) (1936), and to setting up a nexus of triangular relationships that intimate at least an indirect linkage with Rodchenko via Vertov and Eisenstein. ${ }^{48}$ The latter's influence on Rodchenko, who had designed the poster for The Battleship Potemkin, is salient in Steps (1929), a highangle, tilted shot of a woman carrying her child up a series of steps. Richard Whelan is convinced that Rodchenko 'must have remembered at some level the famous scene in Sergei Eisenstein's 1925 movie The Battleship Potemkin showing the Cossack massacre of civilians - including a woman with a child on the steps - leading down to the harbor of Odessa' ${ }^{49}$ Could a kindred triangle, via Vertov and Eisenstein, lie behind Coppola's Rodchenkoesque angles and unorthodox camera frames? The same applies to Ruttmann's Berlin, which could have been a wonderful pre-Bauhaus study in Neue Sachlichkeit for the receptive young photographer. The film, writes Nora Alter, makes use of an "entfesselte, or "unleashed", camera that roams throughout the city ostensibly indiscriminately filming whatever comes into its path' ${ }^{50}$ The protagonist, the city itself, unfolds its character in a series of what could be described as sharp-focused stills insofar as motion remains external to the camera, stemming either from people or moving objects such as vehicles and factory machines. Through a mostly static camera (except for tracking shots), Ruttmann seizes the movement of the modern metropolis generally 
without pan-tilt and enhances it through montage. Paul Grainge and others see Berlin as a paradigm of 'the cold and savage beauty of New Objectivity' in cinema, while Alter observes that 'the cult of the thing, or the object is integral' to the film. She explains that the 'purported aim' of the New Objectivity was 'to focus on nonmediated perception, on the discovery, description, and perceptual account of things as they were', and considers Ruttmann's visual narrative to be 'steadfast in its belief in realism and its pursuit of objectivity'. ${ }^{51}$ Ruttmann's uncompromising objectivity bears the hallmark of New Objectivity photography as this crystallises, for instance, in the work of Renger-Patzsch, who by the late 1920s had become the movement's major spokesperson with polemical texts that targeted Moholy-Nagy's experimentalism, accusing him of being 'an amateur pictorialist in modern dress'. ${ }^{5}$

In reality, Renger-Patzsch's industrial photographs could have been perfectly taken from Ruttmann's Berlin. The factory funnels of Viktoria Mathias Mine in Essen and Eiserne Hand Mine in Essen (1929), the silos of Gutehoffnungshütte Blast Furnace Works in Duisburg (1928), and the furnace in Chimney Seen from Below, Herrenwyk Blast Furnace Works, Lübeck (1928), ${ }^{53}$ share the same visual vocabulary with the four factory funnels squeezed between two buildings in Act I of Ruttmann's film (11 min 55 sec) - and, as we have seen, with Coppola's Port (figure 5). The same applies to Ruttmann's bottle-capping machine (figure 11) and Renger-Patzsch's Shoemaking Irons, Fagus Works, Alfeld (1926). ${ }^{54}$ The focus on the object itself - the milk bottles in the case of Ruttmann, the shoemaking irons in that of Renger-Patzsch - bespeaks the New Objectivity's fixation with the materiality of the thing and its objective representation, a kind of a double-edged 'objectivity'. The sequence in the factory in particular (12 min 33 
$\sec -14 \mathrm{~min} 50 \mathrm{sec})$ reflects the matter-of-fact approach to industrial materiality as we come across it in Renger-Patzsch's celebrated photographs of the Fagus and Krupp factories. We may safely assume that in 1929 Ruttmann's fixed-point camera must have offered the young Coppola an education in the aesthetics of Neue Sachlichkeit, especially if we think of his Construction Materials (figure 9), of the formal and conceptual 'objectivity' of his medianeras and his Maldonado prints, all photographed in 1929, as well as of photographs like Sin título (Untitled) (1931), whose resemblance to Ruttmann's bottle-capping machine is striking (figures 11, 12). Coppola's acquaintance with European avant-garde cinema in August 1929 is at least partly responsible for the burst of the modern that we see in his photographs of that same year.

Machinery and industrial themes may have been woven into the visual fabric of the New Vision in general, but they evidently found a most straightforward rendering in the hands of Neue Sachlichkeit photographers. As already mentioned, the New Objectivity, which had begun as the Weimar era's representational art around 1919, called for a 'return to a tangible objectivity' that 'dominated all other painting styles' throughout the 1920s. Urban and industrial sceneries were stock motifs in the work of German painters belonging to the more conservative strand of Neue Sachlichkeit. ${ }^{55}$ In Argentina, they emerged in the paintings of Coppola's mentor, Alfredo Guttero, who had spent over two decades in Europe before his definitive return to Buenos Aires in 1927. Up until his death five years later, Guttero acted, in de Torre's words, as the 'dean' of the new generation of Argentine painters, and as a 'cultural operator' who, according to Eduardo Costantini, 'confronted the most conservative art tendencies' in the country through participation in juries, educational projects and publications, and the organisation 
of various exhibitions.$^{56}$ Adrián Gorelik states that Guttero was, in fact, 'the only artist that Coppola recognised as having a direct influence on the shaping of his approach', while María Teresa Constantin remarks that elements of the work of New Objectivity artists of the Weimar Republic, notably 'regular volumes, indebted to the new architectural materials and to functionality, doubtlessly evoke Guttero'. Constantin, who speaks of Guttero's industrial paintings dating from 1928 and 1929, quotes a comment on the 'winds of change blowing in Berlin' that the artist made in a letter to his friend and sculptor Luis Falcini in 1921. Guttero, says Constantin, 'is referring to the Neue Sachlichkeit'. She points out that the painter 'shows complete trust in Argentina's industrial development', as did several New Objectivity artists and photographers who took up Germany's interwar faith in industry. ${ }^{57}$ The Neue Sachlichkeit search for a revamped realism formed part of 'the international climate of the return to order' that occurred in the second and third decades of the twentieth century, and involved a raft of aesthetic movements, including the Italian Novecento and its call for a 'return to rational, ordered painting ${ }^{58}$ Constantin draws attention to the link between the New Objectivity and Italian Novecento, noting that in both cases 'man behaves a bit like a machine' ${ }^{59}$

The generation of Argentine artists who travelled to Europe from 1923 onward, according to Patricia Artundo, 'worked in an environment that emphasized overcoming the aesthetic and artistic questioning of the historical avant-garde and recovering the classical tradition ${ }^{60}$ Guttero, of course, had experiential knowledge of the fermentation that was taking place in the cauldron of European art. In another letter to Falcini dated 1925, he spoke highly of the Novecento exhibition at the $14^{\text {th }}$ Venice Bienniale. The galleries of Novecento art, he wrote, are 'the best in the entire exhibition due to their firm 
grip of modernity, the soundness of the works and the certain tastes that they demonstrate' ${ }^{61}$ Guttero's familiarity with the Novecento and the New Objectivity is manifest in his industrial landscapes from 1928. The Elevadores de granos (Grain Elevators) (1928) (figure 13), with the imposing salmon-coloured building at the centreleft of the composition, the metallic bridge that divides the painting horizontally and the silos in the background, approximates Carl Grossberg's Brücke über die Schwarzbachstraße in Wuppertal (Bridge over Schwarzbach Street in Wuppertal) (figure 14), with its striking brick-red bridge pylons and the sharp-focused background buildings. Notwithstanding that both painters make use of light-green, grey and ochre, Guttero's more pastel-like colours set him apart from the sharpness in form and colour that one encounters in Grossberg. Pastel-like colours are more pronounced in Silo, Silos (ca. 1928) and Puerto (1928), the geometricised cityscape of Sin titulo (Untitled), and the industrial topography of Paisaje de Puerto Nuevo (Landscape of Puerto Nuevo) (1928) (figure 15), whose three factory funnels against the left background break further away from Grossberg's punctilious stroke at the same time that they chime in harmoniously with the visual idiom of straight photography and the New Objectivity, as seen in the work of Sheeler, Renger-Patzsch, Ruttmann and Coppola, among scores of others (figure 5). ${ }^{62}$

Guttero's Grain Elevators and Landscape of Puerto Nuevo betray a strong conceptual and to a certain degree formal kinship with the quest of the New Objectivity for Sachlichkeit, making them another odds-on favourite for bringing Coppola closer to the movement's cult of the object. As Schwartz affirms, Guttero's 'tubular silos, monumental in their volumetric geometry $[\ldots]$ were essential in shaping Coppola's approach,. ${ }^{63}$ Coppola met Guttero when the latter opened his fourth 'one-man show' at 
the Amigos del Arte on 30 September 1929, where he most likely exhibited his industrial sceneries. ${ }^{64}$ Impressed by the exhibition, the young Coppola gave Guttero a six-page-long letter discussing his paintings, while their meeting signalled the beginning of a long 'friendship and a partnership' ${ }^{65}$ Clearly, Guttero's role was key to keeping Coppola au courant with the latest developments in the European art scene and the retour à l'ordre. In his 'Autobiographical Text', the photographer reveals that it was Guttero who in 1929 'urged' him to travel to Europe and 'planned an itinerary' (containing several visits to museum and galleries, such as the Novecento exhibition in Rome mentioned earlier) which he 'duly followed' a year later. ${ }^{66}$

To paraphrase Gorelik, the year 1929 and more specifically the months from August to November were Coppola's menses mirabiles ${ }^{67}$ since, to his crash course in European avant-garde cinema and his discovery of Guttero's work, we should add the ten lectures on architecture that Le Corbusier gave at the Amigos del Arte and the Faculty of Exact Sciences in Buenos Aires in October $1929 .{ }^{68}$ Nurtured on the principles of constructivism and functionalism, Le Corbusier's abstract architecture fascinated Coppola who, lured by the 'modern' vision of the Swiss architect, would later recall his lectures, particularly 'his survey of Buenos Aires, on which [his] future photographs would be based' ${ }^{69}$ In his 1995 interview with Gorelik, Coppola harped on the 'decisive influence' that Le Corbusier had exerted on his 'way of seeing the city'. ${ }^{70}$ The latter severely criticised Buenos Aires for its lack of green areas and its anachronistic use of the cuadricula, or Spanish-square planning, describing it as 'one of the most inhuman cities [he] [had] known'. ${ }^{71}$ For all Coppola's emphasis on the impact Le Corbusier had on his work, the grid system that the Swiss shunned so vehemently was, in fact, wholeheartedly 
cherished by the Argentine. Testimony to this is a photograph of a whitewashed suburban house taken in 1929 and rephotographed seven years later for the purposes of his album Buenos Aires 1936 (figures 16, 17). ${ }^{72}$ The change of angle in the retake, says Gorelik, resulted in the accentuated esquina (corner), which constitutes 'one of the key points in understanding the grid system', the real theme of the photograph, according to the original title: Esquina en las antiguas orillas. Calle Paraguay al 2600 (Street Corner in the Old Limits of the City. 2600 Paraguay Street). Coppola's '1936 "corrections" to the 1929 photograph', the scholar rightly concludes, 'can be seen as a subtle defence of the block', especially because this is the only photograph known to have been repeated by Coppola. $^{73}$

In a typical avant-garde gesture, Le Corbusier attributed aesthetic quality to the suburban little houses. Through 'the ennobling of the banal,${ }^{74}$ he made use of the image of porteño immigrant housing to eschew European architectural academicism which, in his view and in that of many others in the audience, had plagued Buenos Aires as a consequence of the longstanding Eurocentrism of its political élite. From the Europhile president Bernardino Rivadavia, under whose governance the French neoclassical façade of the Metropolitan Cathedral of Buenos Aires was completed in 1926, to the so-called Generation of the 1880 s, who, in an attempt to distance themselves from anything that could hark them back to the colonial past, asserted an eclecticism that drew heavily and often uncritically on French, German, and British architecture, any traces of colonial architecture in the capital city were systematically wiped out, giving way to a hotchpotch of European architectural styles. Le Corbusier asked his audience to turn their back on academicism and instead embrace the popular cubism of the little houses. 'You have 
this', he professed, 'a standard plan, and a play of forms in the Argentine light, a play of very beautiful, very pure forms. Look!'. The study of this 'folklore for mass production', he reasoned, could give rise to 'a pure functional organism'. ${ }^{75}$ Enraptured by the architect's appraisal of popular functionalist architecture, Coppola clung to the spontaneous cubism of the immigrant houses for their alleged affinity with architectural modernism. The assumed connection between the simple, functional, and nondecorative structure of the suburban houses and interwar modernist architecture was also underscored by the German architect and city planner Werner Hegemann, who visited Buenos Aires following an invitation from the Amigos de la Ciudad two years later. For Hegemann, the cubist precepts of contemporary European architecture did not have to be imported to South America because they emanated 'naturally' from its own 'healthy tradition'. 'Even today', he posited, 'construction companies erect thousands of small houses that fall completely within classic form, houses which have been simplified and stripped of baroque trappings, giving themselves wholeheartedly and innocently to a very modern materialism $[$ Sachlichkeit $] \cdot{ }^{76}$ By shooting the Sachlichkeit of the little houses, the Argentine kept pace, among others, with the most recent happenings in the European art world. This keenness on functionalism and materialism through Le Corbusier bespeaks yet another oblique link with Neue Sachlichkeit.

The year 1929 may signal Coppola's immersion in European art, but the photographer had plugged into it since at least 1924 with the appearance of Martin Fierro (1924-1927), the country's most important avant-garde magazine, which he 'used to buy at the news-stand' on the way back from the Mariano Moreno secondary school. ${ }^{77}$ Ever since, his acquaintances, friendships, and collaborations with intellectuals and artists, 
some of them prominent members of the Buenos Aires avant-garde, kept him up to date with aesthetic gestation across Europe. Among them, for example, we find Jorge Luis Borges, a leading figure of the literary avant-garde with whom Coppola ventured his 'long walks around Maldonado', taking pictures of suburban neighbourhoods and houses (figure 16), ${ }^{78}$ and de Torre, his partner at the Cine Club, the Amigos del Arte, and the Martin Fierro group, and co-founder of the influential Spanish magazine La Gaceta Literaria (1927-1932), the main vehicle for the dissemination of European avant-garde art and literature in Spain and Spanish America, with a wide distribution in Argentina. Essays on German Expressionism, the New Objectivity, Cubism, and Italian Futurism populated the pages of La Gaceta during the five years of its circulation. By the time de Torre moved to Argentina (he married Borges's sister, Norah), he had already published his book Literaturas europeas de vanguardia (European Avant-Garde Literatures) (1925), which made a strong impression in Latin America, becoming, in the words of the Cuban writer Alejo Carpentier, 'a kind of Bible' for Latin American literati. ${ }^{79}$ De Torre, whom Ernesto Giménez Caballero, the co-founder of La Gaceta, considered an authority on avant-gardism 'for his extraordinary erudition in all the -isms', was no doubt key to Coppola's aesthetic education and particularly to his attunement to the new artistic vocabularies of Europe ${ }^{80}$ While in Argentina, de Torre continued to act as La Gaceta's secretary until 1929, and contributed regularly to José Ortega y Gasset's legendary journal Revista de Occidente between 1923 and 1936. Coppola, who had subscribed to the Revista in 1925, read Ortega y Gasset's influential essay El tema de nuestro tiempo (The Modern Theme) (1923), after being prompted by Francisco Romero, who would later become 'one of Argentina's most outstanding philosophers' ${ }^{81}$ It was there, observes 
Gonzalo Aguilar in a note, where the Spaniard 'expound[ed] his rejection of rationalism and relativism in favour of "perspectivism" and his doctrine of the point of view, which can also be traced in Coppola's definition of the "imagema"'. 'Ortega's powerful influence', continues Aguilar, is also 'evident in Coppola's use, in essays, of quotations from articles and books by Ortega generally published by Revista de Occidente ${ }^{82}$ In the tenth chapter of The Modern Theme, entitled 'The Doctrine of the Point of View', the Spanish philosopher considered perspective as 'one of the component parts of reality', arguing that 'a reality which remained the same from whatever point of view it was observed would be a ridiculous conception, ${ }^{83}$ This admittedly resonated with the young Coppola, who would soon adopt the maverick perspectives of the New Vision, but also with Romero, a philosopher preoccupied with the notion of historical perspective and a major translator of works from German into Spanish. ${ }^{84}$ Like de Torre, Romero, whom Coppola viewed as 'a brother and mentor, ${ }^{85}$ must have played a crucial role in making Coppola conversant with the latest intellectual developments in Europe, while Ortega helped him fashion his unorthodox visuality quite early on, a fact that would later allow him to feel at home with the new visual glossaries of Europe and the United States.

Coppola's dialogue with European and North American photography is evident in his pictures and theoretical writings alike. The text accompanying the invitation leaflet for what is widely held as the first exhibition of modern photography in Argentina, a joint enterprise of Coppola and Stern at the offices of Sur in 1935, was, according to the former, a reproduction of a text written by Peterhans. ${ }^{86}$ Christopher Phillips explains that Peterhans's philosophy 'was considerably closer to Renger-Patzsch's than to Moholy' ${ }^{87}$ The text spotlighted 'the free, subjective activity of the photographer', whose selection of 
the object presupposed a personal understanding: 'the photographer expresses his intuition of the object, his understanding, his knowledge of the object' and in so doing, he provides 'an essentially new opportunity for knowing and expressing, thanks to its specific ability to detail and "highlight" the reality of those people and things' ${ }^{88}$ The text of the invitation was cast in the same conceptual mould as Strand's manifesto on straight photography. 'It is in the organization of this objectivity that the photographer's point of view toward Life enters in', avowed Strand in $1917,{ }^{89}$ and his remarks were echoed by Ortega y Gasset, who, a year earlier, had published his first formulation of perspectivism in El Espectador. ${ }^{90}$ Far from 'disturbing' the 'fabric' of 'reality', argued Ortega y Gasset, perspective constitutes reality's 'organising element'. 'The persistent error that has hitherto been made', he wrote, 'is the supposition that reality possesses in itself, independently of the point of view from which it is observed, a physiognomy of its own'. ${ }^{91}$ At more or less the same time, Ortega y Gasset and Strand understood perspective as a constitutive element of reality, and spoke of a new way of seeing. The philosopher and the photographer coincided in their novel mode of $\theta \varepsilon \omega \rho \varepsilon \tilde{\imath} v$ (to observe, contemplate, theorise), and so did Coppola about a decade later. We may never ascertain whether the Argentine became acquainted with the work of Strand via Ocampo in 1930, but we do know that by then he was at ease with Strand's vision thanks to his early attachment to Ortega y Gasset's perspectivist theory.

Commenting on Strand, Joel Eisinger stresses that 'despite his claims for the objectivity of photography and his demand that the photographer respect the thing in front of the camera, Strand still thought of serious photography as expression, as something guided by intuitive knowledge'. The debate on the 'straightness' or 'purity' of 
American photography, adds Eisinger, "paralleled one then taking place in Germany among critics of Neue Sachlichkeit photography'. ${ }^{92}$ Coppola's and Peterhans's statements, for instance, summoned up Roh's 1925 definition of magical realist (or New Objectivity) painting - namely his thesis that 'to depict realistically is not to portray or copy but rather to build rigorously, to construct objects that exist in the world in their particular primordial shape'. ${ }^{93}$

Coppola's and Peterhans's insistence on the ability of the photographer to create, through her or his intuitive perception and personal optik, 'new' opportunities for epistemic breakthroughs by offering novel views of reality, is equally impregnated with the New Vision quest for a radical change of our perspective and, more generally, the avant-garde search for a new sensibility. 'We don't see what we look at. We don't see the extraordinary perspectives, the foreshortenings, and positions of objects. We who are accustomed to seeing the usual, the accepted, must reveal the world of sight. We must revolutionize our visual reasoning', declared Rodchenko in $1928 .{ }^{94}$ Three years earlier, Moholy-Nagy had announced the advent of a new vision: 'We may say that we see the world with entirely different eyes'. The latter held that 'the photographic camera [can] make visible existences which cannot be perceived or taken in by our optical instrument, the eye; i.e. the photographic camera can either complete or supplement our optical instrument, the eye ${ }^{95}$ An almost identical comment was made by Coppola in his essay 'On Photography' (possibly co-authored with Stern), which was published in the third issue of Campo Grafico: Rivista di Estetica e di Tecnica Grafica in Milan in 1937: 'We look with our eyes and we see things, objects. Only rarely do we look at objects in order to see them for themselves', he wrote. ${ }^{96}$ He concluded: 
These objects are made of a given material, they have a given surface, shape, colour, volume. A book is smooth or rough paper, ink, a number of pages, a prism. This material, this surface, shape, volume, reflects part of the light that illuminates it; they are visible objects, objects that exist for the camera. [...] In certain cases, these bodies may only reflect part of the light; like infrared rays, they are not visible to the human eye, but they are visible to the camera. ${ }^{97}$

The text sounds like a redrafting of Renger-Patzsch's Sachlichkeit aesthetics. 'To capture impressions of nature, plants, animals, works by architects and sculptors, engineers and technicians', the German photographer postulated in his 1927 article 'Goals', 'we have the most appropriate tool at our disposal in photography. [....] The individualized structure of wood, stone and metal can be depicted exceptionally well, and in a manner that would be impossible to achieve with the means available to the visual arts'. Also, he added in defence of a purely factual photography: 'The absolute correct reproduction of form, the subtlety of shading from the highest point of light to the deepest shadow, confers on the technically excellent photograph the magic of the experience itself ${ }^{98}$

Renger-Patzsch's appeal for faithfulness to the material was shared by Coppola and so was Moholy-Nagy's and Ortega y Gasset's perspectivism. 'An image', clarified Coppola, 'is obtained of the shape of the object and its volume, which can be characterised as an image from a point of view'. ${ }^{99}$ Each photograph yields an individual point of view, in the same way that, according to Ortega y Gasset, 'all knowledge is knowledge from a definite point of view'. 'By setting everyone's fragmentary visions 
side-by-side', the latter argued, 'it would be possible to achieve a complete panorama of absolute and universally valid truth' ${ }^{100}$ Coppola reiterates Ortega y Gasset's notion of visual and epistemic fragmentation: 'The photographic image is a fragment of reality. $[\ldots]$ The photographic image is the image of a fragment of reality: it is a rectangle which exactly individualises that fragment, limiting it, separating it, framing it as a new visual unit'. ${ }^{101}$ The same statement is repeated in his 'Definition of Imagema', originally published in 1994: 'My work is an optical image of the real, transcribed by the camera and obtained in the final image, it is the proof of my authorship: a proof, an apparent fragment of reality, the creature of my vision, now released'. ${ }^{102}$ As in his 1935 text, Coppola brings together objectivity and expressiveness, as did Strand, albeit unwillingly, in his 1917 manifesto, at the same time that he conjures up Rodchenko's call for a new visual idiom. 'The faithfulness of photography is the element itself', he notes, 'bent to the will of the photographer who aims to fix on paper his vision of the visible reality'. Photography, insists Coppola, 'is an instrument at the service of anyone aware of that reality, ${ }^{103}$

Coppola's major theorisation of the medium is found in 'Imagema', a leaflet that the photographer used for his exhibition 40 años de fotografia (Forty Years of Photography), which was held at the Museo de Arte Moderno in Buenos Aires in 1969. I say 'major' because, temporally distant from the shocks and jolts of the avant-garde, this was his bid to afford a fairly idiosyncratic account of his photographic vision, one that nevertheless still bore visible traces of an avant-gardist past. Cited in the epigraph to the text, Paul Valéry's words could have come out of the mouth of any New Vision photographer: 'To see all the things in the world as if they had never yet been seen'. ${ }^{104}$ In 
a typically straight photography and New Objectivity fashion, Coppola maintained that 'IMAGEMA is pure reality; it is the image in its essential being'. For him, 'this pure reality is born visible, it becomes visible through the contact $[\ldots]$ of the subject who is looking with the object looked at'. Referring to the faithfulness, or objectivity, of photography, he explained that 'THE PHOTOGRAPHIC IMAGE matches the image on the human retina, but our perception of that image is not necessarily faithful'. We learn that this is because 'the psyche, with all its emotions, all its private complexities, conscious or unconscious, partially ignores - sometimes totally ignores - that part of the image not related to a given act, to the object's function'. Free from this emotive dimension, the camera lens 'allows us to capture pure reality, its visible elemental being, its imagema ${ }^{\text {, }}{ }^{105}$ To some extent, of course, Coppola's argument implodes because the non-emotive objectivity of the camera is tainted with the subjectivity of the eye of the photographer, who organises this objectivity, and with that of the viewer, who sees and necessarily interprets it through emotive mechanisms - Roland Barthes's punctum, or personal meaning, is highly relevant here. ${ }^{106}$ Siegfried Kracauer was quick to undercut the claims of straight and New Objectivity photography to pure objectivity. 'Actually there is no mirror at all', he wrote. 'Photographs do not just copy nature but metamorphose it by transferring three-dimensional phenomena to the plane, severing their ties with the surroundings, and substituting black, gray, and white for the given color schemes'. Kracauer found the most compelling case against the objectivity principle 'in the way in which we take cognisance of visible reality', which 'spontaneously structures the inflowing impressions'. ${ }^{107}$ 
Be that as it may, Coppola's thesis reverberated with Moholy-Nagy's reflections on the supplementary value of the camera vis-à-vis human vision and with RengerPatzsch's reference to the 'subjective eye', which 'views with pleasure the essential things and completely overlooks what is unimportant', while the camera is capable of 'see[ing] the essential and inessential with equal clarity'. ${ }^{108}$ It was also in accord with Roh's belief that New Objectivity painting is able 'to endow the viewer, who is frequently too cursory and careless in his knowledge of the world and in his idealism, with a penetrating and meticulous lucidity'. ${ }^{109}$ Roh's and Coppola's reasoning was in line with that of New Objectivity artist Grethe Jürgens, who in 1932 joyously spoke of 'the discovery of a totally new world'. 'One paints pots and rubbish piles', asserted Jürgens, 'and then suddenly sees these things quite differently, as if one had never before seen a pot. One paints a landscape, trees, houses, vehicles, and one sees the world anew. One discovers like a child an adventure-filled land, ${ }^{110}$

As noted earlier, Coppola's definition of 'imagema' as 'ONE of the possible definitions of the VISIBLE, one of the infinite definitions that light gives to vision', explicitly embraced Ortega y Gasset's theory of perspectivism and the subjective expressiveness of the photographer as 'author' of images. The photographer, writes Coppola, is 'the man who looks, sees, finds, invents, CHOOSES what can be illuminated, $[\ldots]$ the man who sees the skin of the world, of its gestures, of its perspectives'. And he concludes: 'IMAGEMA; image-testimony, a being that transcends. PHOTOGRAPHY as a method, as a philosophy of truth'. ${ }^{111}$ Coppola's final remark champions the philosophical underpinnings and epistemological value of the medium, and brings to mind the comments Thomas Mann made about Renger-Patzsch's aesthetic 'objectivity'. 
The latter, observed Mann, 'identified what is individual and objective out of the to-ing and fro-ing of the world perceived through the senses, isolated it, elevated it, intensified it, rendered it significant, given it a soul'. ${ }^{112}$ Like Renger-Patzsch, Coppola's lens shoots the essence of the object and, fragmentarily, of the world surrounding it. Seeing photographically, to use Weston's terms,${ }^{113}$ is to know. In his 'Autobiographical Text', the Argentine ponders on the etymological significance of the verb 'to look' in Spanish: 'I started to look (Spanish mirar, from Latin: mirare, from miror: TO SEE WITH WONDER and EAGERLY; from the Sanskrit root: mare, to distinguish)'. The one who looks eagerly and respectfully at the object, produces imagemas, or fragments of knowledge. Coppola detects this overlap between vision and cognition in the words of the French philosopher and Jesuit priest, Pierre Teilhard de Chardin: 'SEEING. We might say that the whole of life lies in that verb - if not ultimately, at least essentially [...] [in order] to KNOW' ${ }^{114}$ The argument on photography as an epistemological tool has seemingly run full circle because, from its inception, the medium has been used in scientific research, a fact that prompted the pictorialist crusade to restore photography as an art form. But in contrast with scientific photography, says Coppola, the epistemological value of the medium as art consists not in reproducing external reality faithfully, but in 'seeing' the essence of that reality, or in seeing it anew. In doing so, the art of photography can unlock new layers of meaning, amplifying our scope of visibility. Photography and philosophy emerge as two overlapping modes of $\theta \varepsilon \omega \rho \varepsilon \tilde{\nu} v$.

I have argued that while Coppola's engagement with New Vision and New Objectivity photography culminated in the dizzying angles, tilted frames, shadows and industrial themes of his 1931 pictures, his dialogue with European avant-garde 
photography can be traced back at least to the prodigious year of 1929 , and more specifically to his attention to Sachlichkeit and his formal experimentation. It is clear that by 1929 , the photographer had already been nurtured by an impressive range of sources, some more acknowledged than others and some most likely hushed up. Although he was eager to blurt out the impact an architect, a painter, a poet, or a philosopher may have had on his work, he was far less keen to disclose his photographic readings, pre- or postBauhaus. As noted earlier, save his brother Armando, the only two twentieth-century photographers that Coppola recognised as his 'maestros' were American - Stieglitz and Weston, both former pictorialists who had espoused straight photography by the early 1920s. ${ }^{115}$ 'He shared the common American anxiety about artistic dependence on Europe and wanted independence and international respect for American art', mentions Eisinger with respect to Strand, but his comment could easily apply to Coppola. ${ }^{116}$ Entangled in issues of origin and imitation, different Latin American avant-garde movements sought to cut the umbilical cord with Europe in terms of cultural dependence. In Argentina, where 3,300,000 immigrants arrived, mainly from Italy and Spain, between 1857 and 1914, questions of origin and national culture were high on the agendas of politicians and literati alike. By 1910, Buenos Aires had transformed from a 'gran aldea' (large village) and a 'modest trade and political centre' of about 180,000 residents in 1870, into 'a major world port and a metropolis with a population of $1,300,000,{ }^{117}$ Crucially, about twothirds of those people had not been born in Argentina. ${ }^{118}$ Foreign-born men, according to David Rock, 'still represented 40 per cent of the male population in $1930, .{ }^{119}$ This radical alteration of demographics together with rapid urbanisation and modernisation raised complex sociopolitical, ideological, and aesthetic issues, one of which was to redefine 
national cultural identity. Concerned with things Argentine in an era of mass immigration, the Buenos Aires avant-garde to which the photographer belonged, vacillated between the reformation of national culture and aesthetic renovation through the tenets of European avant-garde movements.

Born into a wealthy family of Italian immigrants who had settled in Argentina in the late nineteenth century, 'Coppola studied at a number of State primary schools, which provided a high level education and sought to encourage the integration of Argentina's many immigrants' ${ }^{120}$ While still at school, we have seen that he was nourished by the aesthetic precepts of the avant-garde magazine Martin Fierro, thus becoming involved in the Martinfierristas' project to revamp national culture very early on. Their vision to renew tradition and forge a new aesthetic language which would be at once distinctly americano and at pace with aesthetic developments internationally was reflected in the choice of name for the magazine: Martín Fierro was the title of Argentina's national epic written by José Hernández between 1872 and 1879. By the late 1910s, Hernández’s gauchesque poem, which celebrated the free-spirited gaucho (cowboy) of the Pampa, had been canonised based on apparently offering a true image of Argentineness in an age when the country's long-established institutions and structures were being dismantled as a result of the massive influx of immigrants and the processes of modernisation. In Anthony Giddens's terms, this radical 'disembedding' of traditional social systems and cultural codes inaugurated a series of ideological antinomies which dominated the social, political and aesthetic debates of the time: rural (the Pampa) or urban (Buenos Aires)? Tradition or modernity? American or European? ${ }^{121}$ Don Segundo Sombra (1926), a novel written by Ricardo Güiraldes, a prominent member of the Martín Fierro group, was 
largely a re-examination of the figure of the gaucho at a time when typical Argentine gauchos were disappearing, and a mise-en-scène of those ideological antinomies as it held the tensions between a Europeanised lifestyle and a life in the Pampa. ${ }^{122}$ Commenting on a photograph taken at the launch of the book and published in the thirtysixth issue of Martin Fierro (12 December 1926), Coppola wrote about the Martinfierristas (many of whom were members of the Amigos del Arte): 'Thirty-three people, including Ricardo Güiraldes himself. All, or almost all, the people that were, or would shortly be, our betters. My joy: to be their young contemporary'. ${ }^{123}$ I have already argued that Coppola's apprenticeship in the circles of Martin Fierro and the Amigos del Arte, which he described as 'an exemplary body' and 'a varied cultural watershed', shaped his aesthetic outlook and acted as a catalyst for his search for a new visual glossary that would allow Argentine art to slip its moorings in Europe and put an end to a long history of cultural dependence. ${ }^{124}$

For Strand, observes Brizuela, 'American photographic production was unencumbered by the weight of tradition and by the "anxiety of influence", partly because it was such a recent development $[\ldots]$ and partly because its practitioners were mostly amateurs, not worried with debates about art versus science or technology’. ${ }^{125}$ The same could be said of Argentine photographic production, but unlike Strand, Coppola began to mould his visual language when the aesthetics of New Vision and New Objectivity photography were already in full swing. 'Old art', adds Brizuela with reference to Strand, 'the art of the past symbolized in the medium of painting and in pictorialist and figurative aesthetics, belonged in Europe; "new art", the art of the present and of the future was photography and belonged in the USA, the land of amateurs, of 
self-made men and women, of technology and the real, forceful movement of progress' ${ }^{126}$ In pictorialist Argentina, Coppola's photographic idiom was certainly a novelty, but his 'new art' was as new as that of his contemporaries on both sides of the Atlantic. For him, the 'new art' of North America, reflected in the likes of Stieglitz and Weston, may have been an ally in the battle against cultural dependence, but the same was not true for European photography. As a young artist and a member of the Buenos Aires avant-garde, he must have - erroneously but understandably - felt that acknowledging his creative dialogue with photographic developments in Europe would have compromised his personal contribution to the 'new art' within and beyond Argentina.

Coppola's pursuit of a novel visual vocabulary and his tense relationship with innovative European photographic practices bring to mind his fellow Martinfierrista, the painter and polymath Alejandro Xul Solar. As I discuss elsewhere, Xul's participation in the Buenos Aires avant-garde in the 1920s is patent in his Pan-American project, and more specifically in his emphasis on the Bolivarian ideal of 'our America [...] the great Iberian America', in his desire to develop 'our own artistic revolution', and in his invention, quite literally, of a new Latin American language: that is, the neocriollo, or Neo-Creole, a fusion of American Spanish and Brazilian Portuguese with some words from English and German. ${ }^{127}$ 'The rooms at the Museo Nacional de Bellas Artes. An exhibition about German books', recounts Coppola about his first meeting with Xul. 'We introduced ourselves, and Xul Solar - already using his neocriollo words [...] - shared secrets with me'. ${ }^{128}$ According to Schwartz, the neocriollo had 'as its point of departure, the written adaptation of a gauchoized, colloquial language, definitive of what is 
supposedly an Argentine stock, with linguistic expressions that are typical of the Creolist vanguard of the period' ${ }^{129}$ Xul's Pan-American vision was eloquently visualised, among others, in the watercolours Mundo (World) (1925) and Drago (Dragon) (1927), where a flying serpent carrying the flags of Latin American countries dominates the scene. ${ }^{130}$ Through the assimilation of Latin America's different traditions and cultures, the NeoCreoles, he tells us, could pave the way for a new and better world.

Xul's discovery of the Der Blaue Reiter Almanach during his visit in Turin in 1912 seems to have triggered a similar reaction to that of Coppola. The Argentine felt a strong connection with the expressionists' take on utopia and spiritualism, especially with that of Kandinsky with whom he shared an interest in Rudolf Steiner's anthroposophy and Madame Blavatsky's theosophy, but he also felt the need to emphasise his own 'intuitive' originality. In a letter, probably to a family member, in that same year, he spoke of the impact the discovery of the almanac had on him: 'I am very satisfied because, on the one hand, I see how I, on my own, without any inspiration from outside, have worked according to the dominant tendency of the highest art of the future and, on the other, I see how I can stand out among these new artists easily because I have more sense of composition and colour than most of them' ${ }^{131}$ Worried about issues of originality and influence, Xul and Coppola mirror the aspirations and anxieties of a generation of American intellectuals and artists who strove for cultural and aesthetic independence from Europe. 'We are and feel new', wrote Xul around 1924, echoing Strand's own vision of American photography. 'Old and foreign paths do not lead to our new goal. [...] We have reached adulthood but we have not yet finished our wars for independence. The moral tutelage of Europe should end. [...] We do not have, in our brief 
past, artistic geniuses to guide (or tyrannise) us. To the weary world, we should bring a new meaning'. ${ }^{132}$ If Xul, Strand, and Coppola, to borrow Brizuela's words, were 'unencumbered by the weight of tradition', this only applied endogenously, because they all ultimately shared what Eisinger has referred to as 'the common American anxiety about artistic dependence on Europe'. The so-called 'moral', cultural, and aesthetic tutelage of Europe was what these artists, among many others from across the intellectual and cultural spectrum of the Americas, sought to abolish in those years. At the same time, in Argentina the urge to forge a culturally distinct identity was fuelled by the great influx of economic immigrants.

Coppola's partial acknowledgement of his photographic borrowings obviously failed to account for his visual experimentalism in the years from 1927 to 1931, as seen, for instance, in the use of unorthodox angles, tilting frames, and negatives, and of different lenses and prisms in abstract pictures like Prisma de cristal (Glass Prism), Interior de prisma (Interior of a Prism), and Autorretrato (Self-portrait) (figure 18), all three taken in $1928 .{ }^{133}$ It seems that from the barracks of the Buenos Aires avant-garde, Coppola was far more reluctant to confess a European affair than an American connection. His aesthetic genealogy nevertheless bears the marks of a long and fruitful dialogue with Neue Sachlichkeit and the New Vision that helped him articulate the first truly modern photographic language in Argentina and one of the most exciting visual idioms in twentieth-century Latin America.

\section{Captions}


Figure 1. Horacio Coppola, Medianera con aire-luz (Wall with Airshaft), gelatin silver print, 1931. (C) Estate of Horacio Coppola, courtesy Galería Jorge Mara-La Ruche, Buenos Aires, 2016.

Figure 2. Horacio Coppola, Calle Corrientes 3060 (3060 Corrientes Street), gelatin silver print, 1931. (C) Estate of Horacio Coppola, courtesy Galería Jorge Mara-La Ruche, Buenos Aires, 2016.

Figure 3. Horacio Coppola, Portón y grúa (Crane), gelatin silver print, 1931. C Estate of Horacio Coppola, courtesy Galería Jorge Mara-La Ruche, Buenos Aires, 2016.

Figure 4. Germaine Krull, Untitled (Métal), gelatin silver print, ca. 1925-1928. AmsabInstitute of Social History (Amsab-ISH), Ghent. Reproduced by permission of Museum Folkwang, Fotografische Sammlung, Essen.

Figure 5. Horacio Coppola, Puerto (Port), gelatin silver print, 1931. (C) Estate of Horacio Coppola, courtesy Galería Jorge Mara-La Ruche, Buenos Aires, 2016.

Figure 6. Horacio Coppola, Mateo y su victoria (Mateo and his Victoria), gelatin silver print, 1931. (C) Estate of Horacio Coppola, courtesy Galería Jorge Mara-La Ruche, Buenos Aires, 2016. 
Figure 7. Horacio Coppola, Ángulo de escalera (Corner of Staircase), negative, gelatin silver print, 1929. (C) Estate of Horacio Coppola, courtesy Galería Jorge Mara-La Ruche, Buenos Aires, 2016.

Figure 8. Horacio Coppola, Mundo propio (One's Own World), gelatin silver print, 1927. (C) Estate of Horacio Coppola, courtesy Galería Jorge Mara-La Ruche, Buenos Aires, 2016.

Figure 9. Horacio Coppola, Materiales de construcción (Construction Materials), gelatin silver print, 1929. (C) Estate of Horacio Coppola, courtesy Galería Jorge Mara-La Ruche, Buenos Aires, 2016.

Figure 10. Horacio Coppola, Buenos Aires, gelatin silver print, 1931. (C) Estate of Horacio Coppola, courtesy Galería Jorge Mara-La Ruche, Buenos Aires, 2016 and Fundación Telefónica.

Figure 11. Walter Ruttmann, Berlin: Die Sinfonie der Großstadt (Berlin: Symphony of a Metropolis), film still (14m14s), 1927. Deutsche Kinemathek, Museum für Film und Fernsehen, Berlin. Reproduced by permission of Eva Riehl.

Figure 12. Horacio Coppola, Sin titulo (Untitled), gelatin silver print, 1931. (C) Estate of Horacio Coppola, courtesy Galería Jorge Mara-La Ruche, Buenos Aires, 2016. 
Figure 13. Alfredo Guttero, Elevadores de granos (Grain Elevators), oil on board, 58.7 cm x $70 \mathrm{~cm}, 1928$. Private Collection, Buenos Aires.

Figure 14. Carl Grossberg, Brücke über die Schwarzbachstraße in Wuppertal (Bridge over Schwarzbach Street in Wuppertal), oil on board, $70 \mathrm{~cm}$ x $60 \mathrm{~cm}, 1927$. Medienzentrum, Antje Zeis-Loi / Kunst- und Museumsverein, Wuppertal.

Figure 15. Alfredo Guttero, Paisaje de Puerto Nuevo (Landscape of Puerto Nuevo), industrial pigment, plaster and natural gum on particleboard, $61 \mathrm{~cm} \mathrm{x} 71 \mathrm{~cm}, 1928$. Private Collection, Buenos Aires.

Figure 16. Horacio Coppola, Esquina en las antiguas orillas. Calle Paraguay al 2600 (Street Corner in the Old Limits of the City. 2600 Paraguay Street), gelatin silver print, 1929. (C) Estate of Horacio Coppola, courtesy Galería Jorge Mara-La Ruche, Buenos Aires, 2016.

Figure 17. Horacio Coppola, Calle Paraguay, esquina Jean Jaurés (Noroeste) (Corner of Paraguay Street and Jean Jaurés [Northeast]), gelatin silver print, 1936. (C) Estate of Horacio Coppola, courtesy Galería Jorge Mara-La Ruche, Buenos Aires, 2016.

Figure 18. Horacio Coppola, Autorretrato (Self-portrait), gelatin silver print, 1928. (C) Estate of Horacio Coppola, courtesy Galería Jorge Mara-La Ruche, Buenos Aires, 2016. 
I wish to thank Luke Gartlan for his assistance with the review process and help preparing the text for publication, and the two anonymous reviewers for their thoughtful comments and suggestions. I am grateful to the Galería Jorge Mara-La Ruche, Buenos Aires, and the Fundación Telefónica, Madrid, for providing images free of charge. For permission to reproduce the photographs in this article, the author and editor would like to express their gratitude to the family of Horacio Coppola, Eva Riehl and the Museum Folkwang, Fotografische Sammlung, Essen. This work was supported by the Arts and Humanities Research Council under Grant AH/J004790/1. Unless otherwise indicated, all translations from the Spanish are those of the author.

Email for correspondence: ek30@st-andrews.ac.uk

1 - Henry Miller, 'Preface', in Brassai [Gyula Halász], Conversations with Picasso, trans. Jane Marie Todd, Chicago: University of Chicago Press 2002, ix.

2 - David Oubiña writes that before his first trip to Europe in December 1930, Coppola's knowledge of photography was 'basically intuitive' and that 'most probably' he did not have 'the chance to see many modern photos' ('antes de partir hacia Europa, entonces, sus conocimientos sobre fotografía son básicamente intuitivos y, muy probablemente, no ha tenido la ocasión de ver muchas fotos modernas'). David Oubiña, 'La piel del mundo: Horacio Coppola y el cine', in Luis Priamo, Natalia Brizuela, David Oubiña, and Patricia M. Artundo, Horacio Coppola: los viajes, Buenos Aires: Galería Jorge Mara-La Ruche 
2009, 193. See also, Andrea Cuarterolo, De la foto al fotograma: relaciones entre cine $y$ fotografia en Argentina (1840-1933), Montevideo: CdF Ediciones 2013, 233.

3 - Juan Manuel Bonet, 'El siglo de Horacio Coppola', in Horacio Coppola: Buenos Aires años treinta, ed. Juan Manuel Bonet, Buenos Aires: Galería Jorge Mara-La Ruche 2005, 5-12; and Jorge Schwartz, 'Foundation of Buenos Aires: The Vision of Horacio Coppola', in Horacio Coppola: fotografia, ed. Jorge Schwartz, trans. Paul Edson and Araceli Montero, Madrid: Fundación Telefónica 2008, 338-43.

4 - Founded by Victoria Ocampo in Buenos Aires in 1931, Sur was responsible for the dissemination of European and world culture into Latin America for more than forty years. Francine Masiello refers to Sur as 'Latin America's cultural journal of greatest longevity and widest international reputation'. Francine Masiello, Between Civilization \& Barbarism: Women, Nation, and Literary Culture in Modern Argentina, Lincoln: University of Nebraska Press 1992, 146-47. Brizuela points out that the Argentine mass media 'barely' experimented with photography in the 1920s and 1930s. 'Only in Sur', she says, 'the magazine which envisioned itself as part of a global network of high modernist aesthetics and as the translator of this "global modernism" into Spanish, did photography not only appear, but also have a central place during its first decade'. Natalia Brizuela, 'Grete Stern, Horacio Coppola and the Question of Modern Photography in Argentina', Journal of Latin American Cultural Studies, 24:2 (June 2015), 245-46. Coppola's seven photographs were published in Sur, 4 (September-December 1931), while the following issue (December 1931-February 1932) included five more pictures by him. The twelve photographs are reproduced in Luis Priamo, 'El joven Coppola', in Priamo, Brizuela, Oubiña, and Artundo, Horacio Coppola: los viajes, 17. Regarding the 
modern visuality of Siete temas, Verónica Tell observes that 'Coppola ventured beyond the places most commonly replicated in different publications that tended to repeat the traditional iconography of Buenos Aires, or would represent familiar places in a different way. [...] His use of reflections, projected shadows, unorthodox framing and high-angle shots clearly form part of modern photographic language'. Verónica Tell, 'Portraits of Places: Notes on Horacio Coppola's Photography and Short Urban Films', Journal of Latin American Cultural Studies, 24:2 (June 2015), 155.

5 - Natalia Brizuela, 'Horacio Coppola y el extrañamiento de lo real', in Priamo, Brizuela, Oubiña, and Artundo, Horacio Coppola: los viajes, 187-88; and Brizuela 'Grete Stern, Horacio Coppola', 252. Schwartz confirms that Ocampo returned to Argentina with two photographs by Stieglitz, probably from his Equivalents, 'a series of cloud photographs taken obsessively between 1922 and 1930, some of which verticalised - appear to take on a wholly independent identity, as abstractions cut loose from their moorings'. Schwartz, 'Foundation', 340 and 342.

6 - For a selection of photographs, see Priamo, 'El joven Coppola', 13-14.

7 - Paul Strand, 'Photography' (1917), in Classic Essays on Photography, ed. Alan Trachtenberg, New Haven, CT: Leete's Island Book 1980, 141-42.

8 - See Maria Morris Hambourg, Paul Strand Circa 1916, New York: Metropolitan Museum of Art 1998, plates 22, 23, 27, 29, 30, 31 and 33.

9 - Ibid., 32-34.

10 - Schwartz, who calls Moholy-Nagy's book 'the quintessential expression of experimentalism', argues that it 'contains theoretical texts on the new art which were to 
inspire the young Coppola', but without providing more evidence as to when Coppola came across Moholy-Nagy’s work. Schwartz, 'Foundation', 341.

11 - See Andreas Haus, Moholy Nagy: Photographs and Photograms, trans. Frederic Samson, New York: Pantheon Books 1980, plates 16 and 24.

12 - Dziga Vertov, 'Kinocks: A Revolution', in Kino Eye: The Writings of Dziga Vertov, ed. Annette Michelson, trans. Kevin O’Brien, Berkeley: University of California Press 1984, 17-18. Rodchenko's text was originally published as 'Kinoki: Perevoròt' in $L E F, 3$ (June/July 1923), 135-43. A year earlier, he had worked on the titles of Vertov's pioneering newsreel series Kino-Pravda (Film-Truth). See Victor Margolin, The Struggle for Utopia: Rodchenko, Lissitzky, Moholy-Nagy, 1917-1946, Chicago: University of Chicago Press 1997, 126.

13 - Margolin, Struggle for Utopia, 133. For Rodchenko's pictures, see Margolin, Struggle for Utopia, figures 134 and 135. For Coppola's photographs, see Horacio Coppola: fotografia, ed. Schwartz, 196; and Horacio Coppola: Buenos Aires años treinta, ed. Bonet, 41.

14 - Brizuela, 'Horacio Coppola', 187: 'La sincronía entre las fotos de Stieglitz y las de Coppola es más tenue que la familiaridad de este último con Strand, de quien probablemente Coppola no haya visto ni leído nada para 1931'.

15 - See Horacio Coppola, 'Autobiographical Text', in Horacio Coppola: fotografia, ed. Schwartz, 372-73.

16 - Brizuela, 'Horacio Coppola', 187: 'En sintonía, sin lugar a dudas, con las fotografías de la Nueva Visión' and 'Los "Siete temas. Buenos Aires" [...] contienen todos los 
elementos formales de la Nueva Visión europea que Coppola aún no conoce y que no ha aprendido en el taller de la Bauhaus'.

17 - Ibid., 187-88.

18 - Fritz Hensler informed Coppola that the Department of Photography at Marburg had closed and told him about the new Bauhaus in Berlin, which he eventually joined. Patricia M. Artundo, 'Chronology', in Horacio Coppola: fotografía, ed. Schwartz, 361. 19 - See Luis Priamo, 'El joven Coppola', 17. With respect to Moholy-Nagy's Boat, Franz Roh and Jan Tschichold included the negative in Foto-Auge/Oeil et Photo/PhotoEye, ed. Franz Roh and Jan Tschichold, Stuttgart: Akademischer Verlag Dr. Fritz Wedekind \& Co. 1929, 69. A year later, Roh published both positive and negative in Franz Roh, L. Moholy Nagy: 60 Fotos, Berlin: Klinkhardt \& Biermann 1930, 11-12. For Rodchenko's and Kertész's photographs, see, respectively, Margarita Tupitsyn, Alexander Rodtschenko. Das Neue Moskau: Fotografien aus der Sammlung L. und G. Tatunz, Munich: Schirmer/Mosel 1998, plate 29; and André Kertész: His Life and Work, ed. Pierre Borhan, Boston: Bullfinch Press 1994, 181. Finally, for Moholy-Nagy's Gangplank from Above, see Haus, Moholy Nagy, plate 52.

20 - See, respectively, Horacio Coppola: fotografia, ed. Schwartz, 184; Alexander Lavrentiev, Alexander Rodchenko: Revolution in Photography, Moscow: Multimedia Complex of Actual Arts 2008, 86; Horacio Coppola: fotografia, ed. Schwartz, 215, 217 and 222; and Albert Renger-Patzsch: Photographer of Objectivity, ed. Ann and Jürgen Wilde and Thomas Weski, Cambridge, MA: MIT Press 1998, plates 38-55 and 68. 21 - See Ann and Jürgen Wilde and Weski, Albert Renger-Patzsch, plate 29. 22 - See Karen Lucic, Charles Sheeler and the Cult of the Machine, London: Reaktion 
Books 1991, plates 42 and 45. Sergiusz Michalski calls Sheeler 'the American Neue Sachlichkeit painter'. Sergiusz Michalski, New Objectivity: Painting, Graphic Art and Photography in Weimar Germany 1919-1933, trans. Michael Claridge, Cologne: Benedikt Taschen 1994, 192.

23 - Schwartz, ‘Foundation’, 342.

24 - See Photography at the Bauhaus, ed. Jeannine Fiedler, London: Dirk Nishen Publishing 1990, 39.

25 - For more examples of thematic and formal affinities between Coppola's early work and that of contemporary European and North American photographers, see appendix with photographs in Priamo, Brizuela, Oubiña, and Artundo, Horacio Coppola: los viajes, $21-47$.

26 - Priamo, 'El joven Coppola', 16: 'este salto gigante'.

27 - Coppola, 'Autobiographical Text', 372-73.

28 - Oubiña, 'La piel', 193: 'Significativamente la colección de Coppola no abunda en libros sobre fotografía de esa época'. Among the publications Oubiña mentions are books by Jean Epstein, Paul Rotha, Rudolf Arnheim, Henri Diamant-Berger, Béla Balázs, Raymond Spottiswoode, and Léon Moussinac, as well as several issues of Cinema Quarterly, Film Art, L'Art cinématographique and Close Up.

29 - Horacio Coppola, 'Interview', in Horacio Coppola: fotografia, ed. Schwartz, 377.

30 - Priamo, 'El joven Coppola', 16: 'Horacio siempre desestimó la influencia de Peterhans sobre su fotografía en su paso por la Bauhaus'.

31 - See Brizuela, 'Horacio Coppola', 182.

32 - Coppola, 'Autobiographical Text', 373. 
33 - Armando Coppola was a member of the Sociedad Fotográfica Argentina de Aficionados (Argentine Photographic Society of Amateurs), the only photographic society of the time, founded in 1889 by individuals 'of the land-owning classes and social celebrities'. Armando's still lifes covered a range of subjects, including 'texture studies with leaves and stones, compositions with vases of flowers, lamps, dolls and mannequins, tools, dental braces placed on a plaster head to produce a comic effect which hovers between the surreal and the grotesque'. Luis Priamo, 'Before Coppola', in Horacio Coppola: fotografia, ed. Schwartz, 346-48.

34 - Roh's book is a good candidate to have attracted Coppola's attention considering that the photographer strongly admired his work (see Priamo, 'El joven Coppola', 11). Roh's 1925 essay 'Nachexpressionismus. Magischer Realismus' (Post-Expressionism: Magic Realism) was translated into Spanish two years later and published in the Revista de Occidente to which Coppola had subscribed in 1925 (Artundo, 'Chronology', 360). By 1928, his term 'magical realism', which was soon to be replaced by Gustav Hartlaub's 'new objectivity', 'was being applied to the prose of European authors in the literary circles of Buenos Aires', which Coppola frequented. See Irene Guenther, 'Magic Realism, New Objectivity, and the Arts during the Weimar Republic', in Magical Realism: Theory, History, Community, ed. Lois Parkinson Zamora and Wendy B. Faris, Durham, NC: Duke University Press 2005, 61.

35 - Graeff's book was another informal companion to the Film und Foto exhibition. 36 - Schwartz, 'Foundation', 341 (emphasis added). The Spanish version of the article makes the same point: 'estas fotos y textos teóricos serían decisivos en el desarrollo de la mirada de Coppola' (these photographs and theoretical texts would be decisive in the 
development of Coppola's approach). Jorge Schwartz, 'Fundación de Buenos Aires: la mirada de Coppola', in Horacio Coppola: fotografia, ed. Schwartz, 29. For the positive, see Horacio Coppola: fotografía, ed. Schwartz, 237.

37 - Schwartz, 'Foundation', 341. Some representative examples of negatives by Andreas Feininger, Roh, and Moholy-Nagy were included in Foto-Auge, ed. Roh and Tschichold, 4, 64, 65, and 69 .

38 - For Coppola's pictures, see Priamo, 'El joven Coppola', 5-6. For Lenk's painting and Renger-Patzsch's photographs, see New Objectivity: Modern German Art in the Weimar Republic, 1919-1933, ed. Stephanie Barron and Sabine Eckmann, Los Angeles: Los Angeles County Museum of Art 2015, 154 and 155.

39 - For San Gimignano, see Horacio Coppola: fotografia, ed. Schwartz, 232. Priamo informs us that the tilted City Hall balcony of San Gimignano, taken with his brother 'Armando's little 4 x 4 camera' (Coppola, 'Autobiographical Text', 372), is the only surviving photograph of Coppola's first visit to Europe (Priamo, 'El joven Coppola’, 11). 40 - For Barricas, Ramos Mejía, see Horacio Coppola: de la Bauhaus a Buenos Aires, ed. Sergio Baur, Madrid: Galería Guillermo de Osma 2004, 8.

41 - Bonet, 'El siglo de Horacio Coppola', 5: 'ya antes del final de los años veinte, Horacio Coppola había asimilado a distancia, fragmentariamente, el idioma de la modernidad europea, de la Neue Sachlichkeit o Nueva Objetividad, de una Nueva Visión'.

42 - For Priamo's reference to pictorialist Argentina, see 'El joven Coppola', 10. Brizuela points out that 'in 1930, a very successful First International Salon of Photography had been held in Argentina, which privileged a showcase of pictorialist-type 
photographs in the Argentine selection (56 of 358 photographs shown were Argentine, from a couple of dozen photographers). The avant-garde practices already widely prevalent in the medium throughout the Americas and Europe - from Paul Strand, Man Ray, Laszlo Moholy-Nagy and Umbo to Manuel Álvarez Bravo and Tina Modotti - were markedly absent from this first Salon' (Brizuela, 'Grete Stern, Horacio Coppola', 253). As I will argue later, Coppola operated within the context of the Buenos Aires avantgarde, known as the Martin Fierro group, and the Amigos del Arte (both established in 1924), as well as that of the Cine Club (founded in 1929).

43 - Oubiña, 'La piel', 193.

44 - Coppola co-founded the Cine Club with León Klimovsky. The Club counted among its members Alfredo Guttero, Jorge Romero Brest, Jorge Luis Borges, Néstor Ibarra, and Guillermo de Torre. Artundo, 'Chronology', 360-61.

45 - Jorge Miguel Couselo, 'Los orígenes de cineclubismo en la Argentina y "La Gaceta Literaria”, Alicante: Biblioteca Virtual Miguel de Cervantes 2000, n.p., available at http://www.cervantesvirtual.com/nd/ark:/59851/bmcf76b3 (accessed 26 April 2016). The Amigos del Arte, 'a group of young intellectuals and artists who were trying to develop Buenos Aires into an important center of culture' attracted the attention of major European and American intellectuals and artists of the time, including Marinetti, Le Corbusier, Waldo Frank, and García Lorca. Alejandro Lapunzina, Le Corbusier's Maison Curutchet, New York: Princeton Architectural Press 1997, 20-21.

46 - See Cuarterolo, De la foto, 236; and Couselo, 'Los orígenes', n.p.

47 - Guillermo de Torre, “El Cineclub” de Buenos Aires', La Gaceta Literaria, 79 (1930), 5: 'La novedad más considerable que puede presentar el Cineclub de Buenos 
Aires con relación a todos los clubs similares europeos es la abundancia de "films" rusos soviéticos, de aquellos que la censura europea proscribe y que aquí se dan públicamente y sin mayor asombro’.

48 - For Coppola’s documentary short, see Oubiña, 'La piel', 207-08; and Tell, 'Portraits of Places', 162-65.

49 - Richard Whelan, Double Take: A Comparative Look at Photographs, New York: C. N. Potter 1981, 120.

50 - Nora M. Alter, 'Berlin, Symphony of a Great City (1927): City, Image, Sound', in Weimar Cinema: An Essential Guide to Classic Films of the Era, ed. Noah William Isenberg, New York: Columbia University Press 2009, 198-99.

51 - Paul Grainge, Mark Jancovich, and Sharon Monteith, 'Realism, Nationalism and "Film Culture"", in Film Histories: An Introduction and Reader, ed. Paul Grainge, Mark Jancovich, and Sharon Monteith, Edinburgh: Edinburgh University Press 2007, 167; and Alter, 'Berlin', 211.

52 - Christopher Phillips, 'Resurrecting Vision: The New Photography in Europe Between the Wars', in The New Vision: Photography Between the Two Worlds, ed. Maria Morris Hambourg and Christopher Phillips, New York: Metropolitan Museum of Art 1994, 94.

53 - See Albert Renger-Patzsch, ed. Ann and Jürgen Wilde and Weski, plates 24, 35, and 43.

54 - See ibid., plate 56.

55 - Maria Makela, “"A Clear and Simple Style”: Tradition and Typology in New Objectivity', Museum Studies (Art Institute of Chicago), 28:1 (Spring 2002), 39; and 
Guenther, 'Magic Realism', 45-46.

56 - De Torre, 'La nueva pintura argentina', La Gaceta Literaria, 95 (December 1930),

8: 'Alfredo Guttero, quizá el decano de esta muchachada'. Eduardo F. Costantini, 'Presentation', trans. Nicole O’Dwyer, in Guttero: un artista moderno en acción, ed. Marcelo E. Pacheco, Buenos Aires: Malba 2006, 171.

57 - Adrián Gorelik, 'Horacio Coppola, 1929: Borges, Le Corbusier and the "Casitas" of Buenos Aires', in Horacio Coppola: fotografia, ed. Schwartz, 349; and María Teresa Constantin, 'Alfredo Guttero and the Industrial Landscape', trans. Wendy Gosselin, in Guttero: un artista moderno en acción, ed. Pacheco, 201-02.

58 - Patricia M. Artundo, 'Alfredo Guttero in Buenos Aires 1927-1932', trans. Jane Brodie, in Guttero: un artista moderno en acción, ed. Pacheco, 178; and Guenther, 'Magic Realism', 4. Guenther notes that notwithstanding their pronounced differences, Russian Constructivism, Fernard Léger's 'réalisme nouveau', Jean Cocteau's 'rappel à l'ordre', and American straight photography, all belonged to the same context. Guenther, 'Magic Realism', 45.

59 - Likewise, in the work of Guttero, Constantin says, 'the industry is the central motif, but the human presence in the foreground [figure 15] cannot be ignored in spite of its size'. Constantin, 'Alfredo Guttero', 202.

60 - Artundo, 'Alfredo Guttero', 178.

61 - Alfredo Guttero, Guttero-Falcini: epistolario, 1916-1930. Cartas a un amigo, ed. Patricia M. Artundo, Buenos Aires: Universidad de Buenos Aires, Facultad de Filosofía y Letras, Instituto de Teoría e Historia del Arte 'Julio E. Payró' 2000, 57, cited in Artundo, ‘Alfredo Guttero', 178. 
62 - For Guttero's paintings, see Costa Malosetti, Pampa, ciudad y suburbia, Buenos Aires: Fundación OSDE 2007, 52; 'Alfredo Guttero: Silo', Museo Nacional de Bellas Artes, Argentina, available at http://mnba.gob.ar/coleccion/obra/7718 (accessed 27 April 2016); Constantin, 'Alfredo Guttero y el paisaje industrial', in Guttero: un artista moderno en acción, ed. Pacheco, 59; and Guttero: un artista moderno en acción, ed. Pacheco, 88.

63 - Schwartz, 'Foundation', 338.

64 - Artundo, 'Chronology', 361; and Patricia M. Artundo, 'Biographical Chronology of Alfredo Guttero (1882-1932)', trans. Patricia Haynes, in Guttero: un artista moderno en acción, ed. Pacheco, 209. A year later an exhibition on the 'Novecento Italiano' was organised at the Amigos del Arte.

65 - Coppola, 'Autobiographical Text', 372.

66 - Ibid. Guttero had co-founded the Asociación de Artistas Argentinos en Europa (Association of Argentine Artists in Europe). See Marcelo E. Pacheco, 'Curatorial Practice and Fields of Writing: The Case of Alfredo Guttero', trans. Gosselin, in Guttero: un artista moderno en acción, ed. Pacheco, 174.

67 - Gorelik, 'Horacio Coppola', 351.

68 - With the exception of the sixth lecture, which took place at the Amigos de la Ciudad on 14 October 1929.

69 - Coppola, 'Autobiographical Text', 373.

70 - Coppola, 'Interview', 377.

71 - Le Corbusier, Precisions on the Present State of Architecture and City Planning, trans. Edith Schreiber Aujame, Cambridge, MA: MIT Press 1991, 200 and 210. 
72 - Although we do not know whether the 1929 picture, which was originally published in Borges's book Evaristo Carriego (Buenos Aires: M. Gleizer Editor 1930), was taken before or after Le Corbusier's lectures (Gorelik, 'Horacio Coppola', 351), the influence that the latter exerted on Coppola, as the photographer himself acknowledged, is evident in many of his post-1929 photographs.

73 - Gorelik, 'Horacio Coppola', 351.

74 - Ibid.

75 - Le Corbusier, Precisions, 228-29.

76 - Werner Hegemann, 'El espíritu de Schinkel en Sud América', trans. I. Stok, Revista de Arquitectura, 142 (October 1932), 468: 'Las empresas constructoras levantan todavía hoy miles de pequeñas casas que están completamente dentro de las formas clásicas [que] se han simplificado y depurado de los agregados barrocos y se han entregado de lleno, inmediata e inocentemente, a un materialismo [Sachlichkeit $]$ modernísimo. [...] No fue necesario en la América del Sud la importación del cubismo de la posguerra por arquitectos europeos, pues se formó solo, como consecuencia natural y lógica de su sana tradición'. Originally published as 'Schinkelscher Geist in Südamerika', Städtebau, 27:7 (July 1932), 333-41. Cited in Gorelik, ‘Avant-Garde and Classicism: Horacio Coppola's and Facundo de Zuviría's Buenos Aires', in Buenos Aires: Coppola + Zuviría, ed. Adrián Gorelik, trans. Paola del Campo, Buenos Aires: Ediciones Larivière 2006, 208. See also, Jorge Francisco Liernur and Pablo Pschepiurca, La red austral: obras y proyectos de Le Corbusier y sus discipulos en la Argentina (1924-1965), Buenos Aires: Prometeo Libros $2008,159$.

77 - Coppola, 'Autobiographical Text', 372. 
78 - Coppola, 'Interview', 377.

79 - 'Una especie de biblia'. Cited in Juan Manuel Bonet, Diccionario de las vanguardias en España, 1907-1936, Madrid: Alianza 1995, 595; and cited in Trinidad Barrera, 'Historiografía y canon de las vanguardias', in Alma América: in Honorem Victorino Polo, ed. Vicente Cervera Salinas and María Dolores Adsuar Fernández, vol. 1, Murcia: Universidad de Murcia 2008, 111.

80 - Ernesto Giménez Caballero, Memorias de un dictador, Barcelona: Planeta 1979, 60: ‘[...] por su erudición prodigiosa sobre todos los ismos'.

81 - Three years later, Coppola attended Ortega y Gasset's course in philosophy at the Arts Faculty of the University of Buenos Aires. Artundo, 'Chronology', 360.

82 - Gonzalo Aguilar, 'A Passion for Geometry', in Horacio Coppola: fotografia, ed. Schwartz, 354 .

83 - José Ortega y Gasset, The Modern Theme, trans. James Cleugh, New York: Harper \& Row 1961, 90.

84 - Artundo, 'Chronology', 360.

85 - Ibid.

86 - Coppola, 'Interview', 377. For Coppola's and Stern's different photographic modernisms, see Brizuela, 'Grete Stern, Horacio Coppola', 247-56.

87 - Phillips, ‘Resurrecting Vision’, 94.

88 - Coppola, 'Exhibition of Photographs by Horacio Coppola and Grete Stern', in Horacio Coppola: fotografia, ed. Schwartz, 367 (emphasis added).

89 - Strand, 'Photography', 142. 
90 - 'From the year 1913 onwards, I have been expounding, in my university lecture, this doctrine of "perspectivity", which is briefly and arbitrarily formulated in El Espectador, I (1916)'. Ortega y Gasset, The Modern Theme, 92.

91 - Ibid., 90 and 92.

92 - Joel Eisinger, Trace and Transformation: American Criticism of Photography in the Modernist Period, Albuquerque: University of New Mexico Press 1995, 56 and 65.

93 - Franz Roh, 'Magic Realism: Post-Expressionism', trans. Wendy B. Faris, in Magical Realism: Theory, History, Community, ed. Lois Parkinson Zamora and Wendy B. Faris, Durham, NC: Duke University Press 2005, 24.

94 - Alexander Rodchenko, 'The Paths of Modern Photography', in Photography in the Modern Era: European Documents and Critical Writings, 1913-1940, ed. Christopher Phillips, trans. John E. Bowlt, New York: Metropolitan Museum of Art / Aperture 1989, 262. Originally published as 'Puti sovremennoi fotografii', Novyi LEF, 9 (September 1928), 31-39.

95 - Moholy-Nagy, 'Photography' (1925), in Classic Essays on Photography, ed. Trachtenberg, 166 (italics in original).

96 - Campo Grafico: Rivista di Estetica e di Tecnica Grafica, 3 (March 1937). This was a special issue on the work of Coppola and Stern.

97 - Horacio Coppola, 'On Photography', in Horacio Coppola: fotografia, ed. Schwartz, trans. Edson and Montero, 368.

98 - Albert Renger-Patzsch, 'Goals', in Albert Renger-Patzsch, ed. Ann and Jürgen Wilde and Weski, 165.

99 - Coppola, 'On Photography', 368. 
100 - Ortega y Gasset, The Modern Theme, 90 and 95.

101 - Coppola, ‘On Photography', 368.

102 - Horacio Coppola, 'Definition of Imagema', in Horacio Coppola: fotografía, ed.

Schwartz, 377 (original emphasis).

103 - Coppola, 'On Photography', 368-69.

104 - Part of the inscription on the façade of the Palais de Chaillot, Paris, composed by Paul Valéry: 'regarder / comme jamais encore vues / toutes choses qui sont au monde'. Cited in Horacio Coppola, 'Imagema', in Horacio Coppola: fotografia, ed. Schwartz, trans. Edson and Montero, 369.

105 - Coppola, 'Imagema', 369 (original emphasis).

106 - Roland Barthes, Camera Lucida: Reflections on Photography, trans. Richard Howard, New York: Farrar, Straus and Giroux 1981, 26-27 and 43-45.

107 - Siegfried Kracauer, 'Photography' (1960), in Classic Essays on Photography, ed. Trachtenberg, 259.

108 - Renger-Patzsch, ‘Goals', 166.

109 - Roh, 'Magic Realism', 27.

110 - Grethe Jürgens, ‘Rezepte zum ersprießlichen Besuch einer Kunstausstellung’, Der Wachsbogen, 5/6 (January 1932), 8-10, cited and translated in Guenther, 'Magic Realism', 36.

111 - Coppola, 'Imagema', 369 (original emphasis).

112 - Thomas Mann, Reden und Aufsätze, vol. 2, Frankfurt: S. Fischer 1965, 776, cited in Michalski, New Objectivity, 189. 
113 - Edward Weston, 'Seeing Photographically' (1965), in Classic Essays on Photography, ed. Trachtenberg, 169-75.

114 - Pierre Teilhard de Chardin, The Phenomenon of Man, trans Bernard Wall, New York: Harper \& Row 1959, 31, cited in Coppola, 'Autobiographical Text', 370 (original emphasis).

115 - Weston's turn to straight photography was heralded by his 1922 pictures of the ARMCO Steel Plant in Middletown, Ohio (see R. H. Cravens, Edward Weston, New York: Aperture 1988, 7), which 'were a stunning departure from his previous work: sharp-focused, powerful visions of the Armco Steel mills' (Cravens, Edward Weston, $10)$.

116 - Eisinger, Trace and Transformation, 58.

117 - James R. Scobie, Buenos Aires: Plaza to Suburb, 1870-1910, New York: Oxford University Press 1974, 51.

118 - José Ramón Navarro Vera, ‘El Buenos Aires de Borges: paisaje interior versus paisaje construido', in Escrituras de la ciudad, ed. José Carlos Rovira, Madrid: Palas Atenea 1999, 132.

119 - David Rock, 'Argentina 1930-1946', in Argentina Since Independence, ed. Leslie Bethell, Cambridge: Cambridge University Press 1993, 173.

120 - Artundo, 'Chronology', 360.

121 - Anthony Giddens, The Consequences of Modernity, Cambridge: Polity Press 1996, 17. These antinomies were first formulated by Domingo Faustino Sarmiento in his famous essay Facundo: civilización y barbarie (Facundo: Between Civilisation and Barbarism) (1845). Sarmiento, who would later serve as President of Argentina, read the 
tension between the 'American' and the 'European', the 'rural' (Pampa) and the 'urban' (Buenos Aires), as a struggle between 'barbarism' and 'civilisation', and spoke of the inherent duality of Argentine identity.

122 - Ricardo Güiraldes, Don Segundo Sombra, Buenos Aires: Editorial Proa 1926. Born into a family of wealthy landowners, Güiraldes himself had spent his childhood between Europe and the Pampa.

123 - Coppola, 'Autobiographical Text', 372.

124 - Ibid.

125 - Brizuela, 'Grete Stern, Horacio Coppola', 250.

126 - Ibid.

127 - Alejandro Xul Solar, 'Pettoruti', in Alejandro Xul Solar: entrevistas, artículos y textos inéditos, ed. Patricia M. Artundo, Buenos Aires: Corregidor 2006a, 98-99 (original emphasis): 'nuestra América [...], la gran AMERICA IBERICA'. Solar, 'Pettoruti', in Alejandro Xul Solar: entrevistas, artículos y textos inéditos, ed. Artundo, 2006b, 110: 'nuestra revolución artística propia'. In the Spanish-American context, the term criollo (Creole) indicates people of European descent who were born and bred in America. 128 - Coppola, 'Autobiographical Text', 372.

129 - Schwartz, 'Let the Stars Compose Syllables: Xul and Neo-Creole', in Xul Solar: visiones y revelaciones, ed. Patricia M. Artundo, Buenos Aires: Pinacoteca 2005, 200. 130 - Eleni Kefala, “La gran América Ibérica”: humanismo y utopía en los años veinte. El caso de Xul Solar', Revista Canadiense de Estudios Hispánicos, $36: 3$ (Spring 2012), 466-67. 
131 - Unpublished letter received in Buenos Aires on 8 November 1921. Archive of the Fundación Pan Klub-Museo Xul Solar, cited in Jorge López Anaya, 'Xul Solar: una utopía espiritualista', in Xul Solar: una utopía espiritualista, ed. Jorge López Anaya, Buenos Aires: Fundación Pan Klub, Museo Xul Solar 2002, 15: 'Estoy muy satisfecho porque veo cómo yo solo, sin ninguna inspiración de afuera, he trabajado en la tendencia dominante del arte más elevado del porvenir por una parte y por la otra veo cómo podré sobresalir entre estos artistas nuevos fácilmente porque tengo más sentido de la composición y color que la mayoría de ellos' (originally written in Italian and translated into Spanish by López Anaya). For more on Xul's spiritual utopianism in the 1930s, see Eleni Kefala, 'Xul Solar, the Reluctant Utopian', Bulletin of Spanish Studies, 89:2 (February 2012), 253-79.

132 - Solar, 'Pettoruti', 2006b, 99: 'Somos y nos sentimos nuevos, a nuestra meta nueva no conducen caminos viejos y ajenos. [...] Somos mayores de edad y aún no hemos terminado las guerras pro independencia. Acabe ya la tutela moral de Europa. [...] No tenemos en nuestro corto pasado genios artísticos que nos guíen (ni tiranicen). Al mundo cansado, aportar un sentido nuevo'.

133 - See Horacio Coppola: fotografia, ed. Schwartz, 229 and 231. The three pictures were taken with a view camera $18 \mathrm{~cm}$ x $24 \mathrm{~cm}$ (Priamo, 'El joven Coppola', 8). 